\title{
Oral Exposure to Silver Nanoparticles or Silver lons May Aggravate Fatty Liver Disease in Overweight Mice
}

\author{
Jianbo Jia, ${ }^{\dagger}$ Feifei Li, ${ }^{\dagger}$ Hongyu Zhou, ${ }^{\ddagger}$ Yuhong Bai, ${ }^{\dagger}$ Sijin Liu, ${ }^{\S}$ Yiguo Jiang, $"$ Guibin Jiang, ${ }^{\S}$ \\ and Bing Yan* $* \dagger$ \\ ${ }^{\dagger}$ School of Environmental Science and Engineering, Shandong University, Jinan 250100, P.R. China \\ ${ }^{\ddagger}$ School of Environment, Guangzhou Key Laboratory of Environmental Exposure and Health and Guangdong Key Laboratory of \\ Environmental Pollution and Health, Jinan University, Guangzhou 510632, P.R. China \\ ${ }^{\S}$ State Key Laboratory of Environmental Chemistry and Ecotoxicology, Research Center for Eco-Environmental Sciences, Chinese \\ Academy of Sciences, Beijing 100085, P.R. China \\ "State Key Laboratory of Respiratory Disease, Institute for Chemical Carcinogenesis, Guangzhou Medical University, Guangzhou \\ 511436, P.R. China
}

\section{Supporting Information}

ABSTRACT: As the applications and environmental release of silver ions and nanoparticles are increasing, increasing human exposure to these pollutants has become an emerging health concern. The impeding effects of such pollutants on susceptible populations are severely under-studied. Here, we demonstrate that silver nanoparticles (Ag NPs), at a dose that causes no general toxicity in normal mice, promotes the progression of fatty liver disease from steatosis to steatohepatitis only in overweight mice. Exposure to $\mathrm{Ag}^{+}$ions induces the same effects in overweight mice. $\mathrm{Ag}$ NPs rather than $\mathrm{Ag}^{+}$ions cause this disease progression based on our findings that $\mathrm{Ag}^{+}$ ions are partly reduced to Ag NPs in fatty livers, and the toxic effect is correlated with the liver dose of $\mathrm{Ag} \mathrm{NPs,} \mathrm{not} \mathrm{Ag}^{+}$ions.

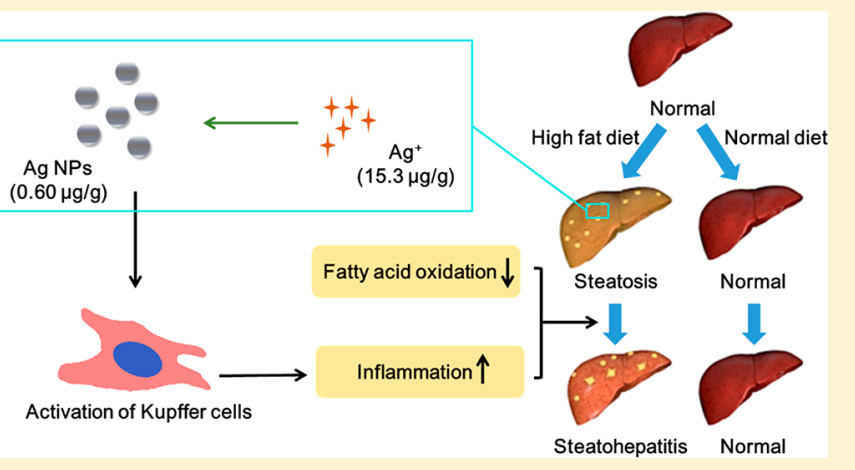
Furthermore, the Ag NP-induced pro-inflammatory activation of Kupffer cells in the liver, enhancement of hepatic inflammation, and suppression of fatty acid oxidation are identified as key factors in the underlying mechanisms.

\section{INTRODUCTION}

Due to their antibacterial properties, silver nanoparticles $(\mathrm{Ag}$ NPs) have been extensively used in a wide range of healthcare and consumer products, including clothing, consumer electronics and appliances, dietary supplements, and medical supplies. ${ }^{1,2}$ The number of Ag NP-based consumer products on the market had reached 442 (out of 1827 nanomaterial-based products) by May of 2017. ${ }^{2}$ The production, usage, and disposal of Ag NP-based products have inevitably increased the environmental accumulation of and human exposure to $\mathrm{Ag}$ NPs. ${ }^{3,4}$ In addition to $\mathrm{Ag} \mathrm{NPs}, \mathrm{Ag}^{+}$pollution is also prevalent. Wide applications of silver compounds in medical fields include silver nitrate, acetate, and sulfadiazine. ${ }^{5} \mathrm{Ag}^{+}$pollution also comes from the photographic, ${ }^{6}$ electrochemical, ${ }^{7}$ and silver mining industries. ${ }^{8}$ A telling example is that in a photoprocessing wastewater sample, $\mathrm{Ag}^{+}$content is as high as 300 $\mu \mathrm{g} / \mathrm{L}$.

Metal ions are readily transformed to nanoparticles under regular environmental conditions. Natural waters containing $\mathrm{Ag}(\mathrm{I})$ and $\mathrm{Au}(\mathrm{III})$ ions generate $\mathrm{Ag}$ NPs and $\mathrm{Au}$ NPs in the presence of natural organic matter upon exposure to either UV or sunlight irradiation. ${ }^{10-12}$ Metal oxide/sulfide nanoparticles, such as $\mathrm{FeS}_{2}, \mathrm{Fe}_{2} \mathrm{O}_{3}, \mathrm{SiO}_{2}, \mathrm{Al}_{2} \mathrm{O}_{3}$, and $\mathrm{MnO}_{2}$, can be formed in nature, depending on environmental factors such as temperature, $\mathrm{pH}$, oxygen, light, concentration, and natural organic matter. ${ }^{13}$ Metal ions can also be converted to nanoparticles in biological bodies such as in plants, ${ }^{14}$ microorganisms, ${ }^{13}$ and animal cells. ${ }^{15}$ Therefore, when $\mathrm{Ag}^{+}$ions are distributed into animal organs, it is likely that a proper reductive microenvironment may convert them to $\mathrm{Ag} \mathrm{NPs}$. The toxicity of $\mathrm{Ag}^{+}$ions has long been recognized. ${ }^{6,7}$ Recently, toxicity of Ag NPs has also been extensively reported. ${ }^{16,17}$ However, in most cases, whether the observed toxic effects are from $\mathrm{Ag}^{+}$ions or from $\mathrm{Ag}$ NPs remains elusive. Furthermore, the impacts of these pollutants on susceptible populations, such as the overweight population, are severely under-studied.

Overweight and obesity have become a prevalent health threat worldwide in both developed ${ }^{18,19}$ and developing countries. ${ }^{19,20}$ According to the WHO, more than 1.9 billion adults were overweight or obese in 2014, among which $69 \%$

Received: June 6, 2017

Accepted: July 19, 2017

Published: July 19, 2017 
(1.3 billion) were classified as overweight individuals, while $31 \%$ (600 millions) were obese (BMI $\left.\geq 30 \mathrm{~kg} / \mathrm{m}^{2}\right) .{ }^{21}$ This significantly large population is still increasing rapidly due to lifestyle changes in many countries and regions. In addition to the risk of heart disease, ${ }^{22}$ diabetes, ${ }^{23}$ and cancer, ${ }^{24}$ overweight and obesity also increase the risk of nonalcoholic fatty liver disease (NAFLD), which is a spectrum of liver abnormalities such as simple steatosis (steatosis without hepatocellular injury), nonalcoholic steatohepatitis (steatosis with inflammation and hepatocyte ballooning degeneration), fibrosis, cirrhosis and, ultimately, hepatocellular carcinoma. ${ }^{25,26}$

Previous studies have shown that the liver is a major organ for deposition of nanoparticles after absorption. ${ }^{27-31}$ A single oral dose of Ag NPs induced acute inflammation of the liver in healthy male BALB/c mice, as evidenced by lymphocyte infiltration and increased expression of genes related to inflammation. ${ }^{32}$ Hepatic inflammation, an increased level of alkaline phosphatase, and infiltration of inflammatory cells in the liver were also observed in healthy Sprague-Dawley rats after a 28-day oral exposure to $\mathrm{Ag} \mathrm{NPs} .{ }^{29}$ These findings indicate that Ag NPs may perturb immune functions in animals, while inflammation is strongly indicated in the development of steatohepatitis. ${ }^{33-35}$ Therefore, a possible role of Ag NPs in causing steatohepatitis needs to be examined.

In this work, we first established a mouse model mimicking the subobese yet significant overweight population by feeding C57BL/6J mice a high-fat diet (HFD) for 8 weeks. Oral exposure to a nontoxic dose of $\mathrm{Ag} \mathrm{NPs}$ or $\mathrm{AgNO}_{3}$ to normal and overweight mice for 2 weeks caused no general toxicity in normal mice. However, an accelerated progression from steatosis to steatohepatitis was observed only in overweight mice, with Ag NPs as well as $\mathrm{Ag}^{+}$ions. We found that after absorption and liver deposition, $\mathrm{Ag}^{+}$ions were partially reduced to Ag NPs only in the livers of overweight mice. The Ag NPs that were either deposited or formed in situ in the livers of overweight mice induced activation of Kupffer cells, led to liver inflammation, suppressed fatty acid oxidation, and caused the transition from steatosis to steatohepatitis.

\section{MATERIALS AND METHODS}

Polyvinylpyrrolidone (PVP)-Coated Silver Nanoparticles. PVP-coated Ag NPs were purchased from Xuzhou Jiechuang New Material Technology Co., Ltd. (Guangzhou, China). The purity of the Ag NPs provided by the manufacturer was $\geq 99.99 \%$. The morphological characteristics of PVP-coated Ag NPs were analyzed by transmission electron microscope (TEM, JEM-1011, Jeol, Japan). The hydrodynamic size and the zeta potential of Ag NPs were measured by a particle size analyzer (Malvern Nano ZS90, Malvern, U.K.). The Ag NPs were dispersed in DI water and sonicated for 30 min before administration.

Animals and Diets. Male C57BL/6J mice (5 weeks old) were obtained from the institute of Laboratory Animal Science, Chinese Academy of Medical Sciences (CAMS) \& Peking Union Medical College (PUMC), Beijing, China. All animal experiments were approved by the Animal Care and Use Committee of Shandong University and were in accordance with the NIH guidelines in "Guide for the care and use of laboratory animals". After acclimation for 1 week, 130 mice were randomly divided into 2 groups and fed a normal diet (ND) or a high-fat diet (HFD, containing 54.8\% ND, 18.9\% lard, $1.3 \%$ cholesterin, $0.3 \%$ cholate, $11.2 \%$ saccharose, $8.7 \%$ casein, $1.8 \%$ premix and $3 \%$ maltodextrin, acquired from
Shanghai Laboratory Animal Center (SLAC), Shanghai, China). Body weight was recorded every week. After 8 weeks, mice in each group were then randomly divided into 5 groups, with one of these 5 groups sacrificed to confirm NAFLD. The other 4 groups of both ND- and HFD-fed mice were administered sterile water, $\mathrm{Ag} \mathrm{NPs}([\mathrm{Ag}]=100$ or 300 $\mathrm{mg} / \mathrm{kg})$ or $\mathrm{AgNO}_{3}([\mathrm{Ag}]=18 \mathrm{mg} / \mathrm{kg})$ for another 2 weeks. Body weight was recorded every day during Ag NP administration.

In Vivo Biodistribution Studies. Tissue samples (the heart, liver, spleen, lung, kidney, small intestine and fat around the small intestine) were added to $10 \mathrm{~mL} 70 \%$ nitric acid and digested in microwave ovens. After dilution with DI water, the $\mathrm{Ag}$ content in the digested solutions was analyzed using an inductively coupled plasma-mass spectrometer (ICP-MS, Agilent 7700, Santa Clara CA, U.S.A.).

TEM and EDX Analysis. The liver samples were dissected into $1-2 \mathrm{~mm}^{3}$ portions in $2.5 \%$ glutaraldehyde immediately after removal from the abdominal cavity and fixed in $2.5 \%$ glutaraldehyde for no less than $24 \mathrm{~h}$. Ultrathin sections were then cut and analyzed with TEM (JEM-2100, Jeol, Japan). The elemental composition of the observed particles was analyzed in situ with an INCA energy dispersive X-ray spectrometer (Oxford Instruments, Oxfordshire, U.K.).

Histopathological Examination. The liver samples were fixed in $10 \%$ buffered formalin for $24 \mathrm{~h}$ and then embedded in paraffin. Paraffin-embedded sections were stained with hematoxylin and eosin staining (H\&E staining). NAFLD activity was scored by an experienced pathologist blinded to the experimental procedures according to the criteria outlined in previous studies. ${ }^{36,37}$ Frozen sections were stained with Oil Red $\mathrm{O}$ staining for further confirmation of the steatosis.

Biochemical Analysis. Liver lipids were extracted with a mixture of chloroform/methanol $(2: 1 \mathrm{v} / \mathrm{v}) .^{38}$ Liver cholesterol was analyzed using a commercial kit according to the manufacturer's protocol (Zhejiang Dongou Diagnostics Co., Ltd., Zhejiang, China). Serum CHOL, TG, and LDL levels were measured using an automatic biochemical analyzer (P800, Roche, U.S.A.).

Statistical Analysis. SigmaPlot 12.0 was used for statistical analyses. One-way ANOVA, followed by least-significant difference or Tukey's tests, was performed to determine significance. Numerical data are presented as the means \pm s.d. Differences were considered significant when $P<0.05$. Unless noted otherwise, all experiments were repeated at least twice with 7 biological replicates and similar results were obtained. No animals were excluded from analysis.

\section{RESULTS AND DISCUSSION}

Overweight Mouse Model. To establish an overweight mouse model, we fed male C57BL/6J mice (6 weeks old) a normal diet (ND) or a high-fat diet (HFD) for 8 weeks. In the second week on a HFD, a noticeable change in body weight (5.6\% higher) of HFD-fed mice was observed (Figure S2a of the Supporting Information, SI). By the end of the eighth week, the body weight of HFD mice was $20 \%$ higher than that of ND-fed mice. Lipids in these mice were more abundant (Figure S2b). Serum levels of cholesterol (CHOL), high-density lipoprotein (HDL), and low-density lipoprotein (LDL) were $47 \%, 38 \%$, and $90 \%$ higher, respectively, in HFD-fed mice compared with those in ND-fed mice (Figure S2c).

A person is classified as overweight if his or her body weight is $10 \%$ heavier than the average ${ }^{39}$ or as obese if the body weight 

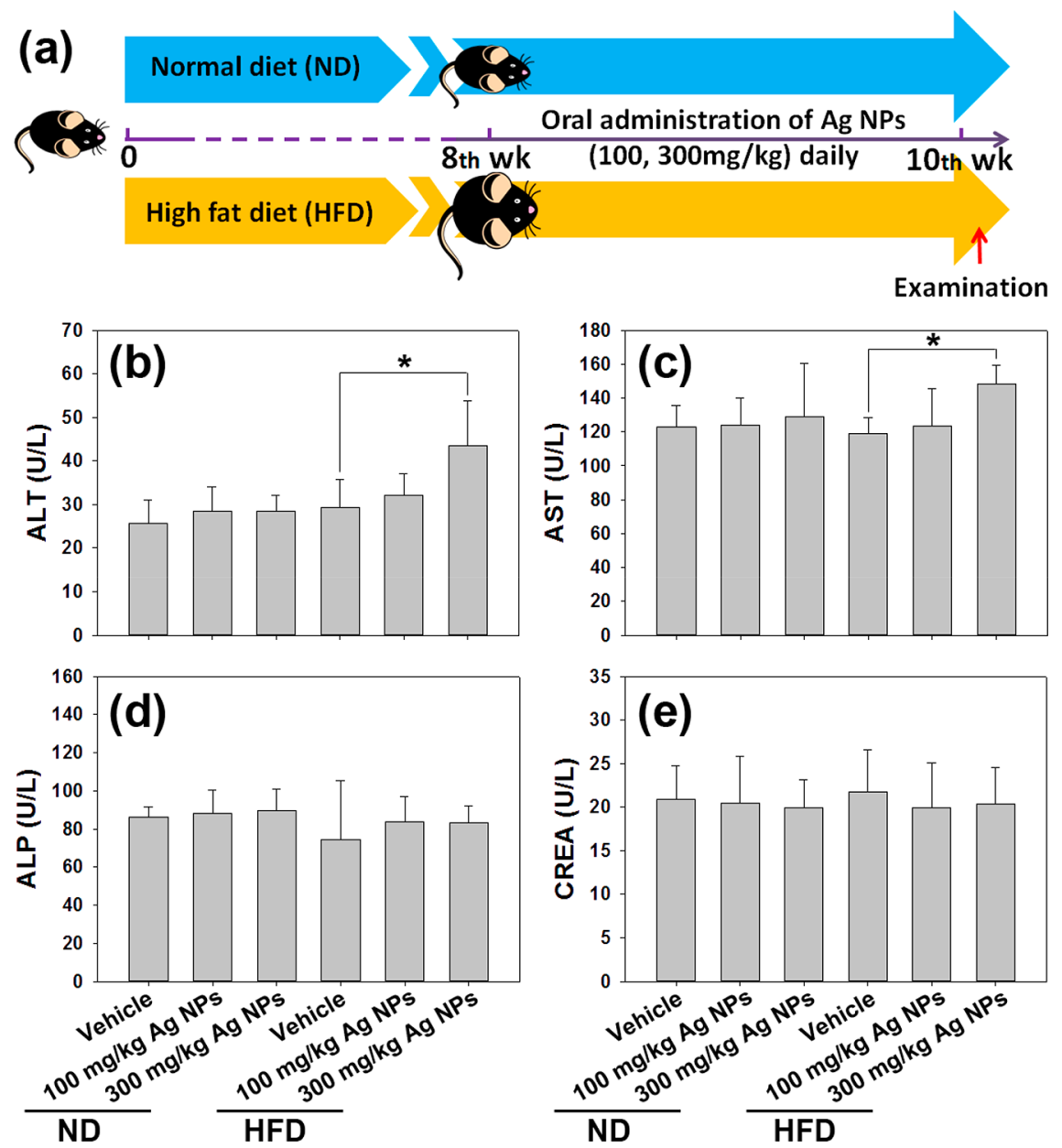

Figure 1. Administration of Ag NPs at different doses to normal/overweight mice and their effects on serum biochemical indexes. (a) ND or HFD feeding and Ag NP exposure schedule. Mice were orally administered Ag NPs (100 or $300 \mathrm{mg} / \mathrm{kg}$ ) daily for 2 weeks after feeding mice a HFD or ND for 8 weeks. (b-e) Serum levels of alanine aminotransferase (ALT, b), aspartate aminotransferase (AST, c), alkaline phosphatase (ALP, d), and creatinine (CREA, e) for the determination of a suitable experimental dose. Data are shown as the means \pm s.d. $(n=7$ per group).

is $20 \%$ heavier. ${ }^{40}$ The translation of the overweight criterion from human to mouse gives a body weight increase of $20 \%$ as overweight. $^{41}$ In this study, an overweight mouse model was established after feeding mice a HFD for 8 weeks as shown by a $20 \%$ increase in body weight, increased abdominal fat and high serum lipids levels. The first question we asked was whether HFD mice were more susceptible than ND mice when orally exposed to Ag NPs.

Doses of $\mathrm{Ag} \mathrm{NPs}$ and $\mathrm{Ag}^{+}$ions. In this study, spherical PVP-coated Ag NPs with an average diameter of $30.0 \pm 4.7 \mathrm{~nm}$ (Figure S1a-b) were used. The hydrodynamic diameters of $\mathrm{Ag}$ NPs, measured by dynamic light scattering (DLS), were $33.6 \pm$ $7.5 \mathrm{~nm}$ in water (Figure S1c), which indicated that Ag NPs were well suspended in water. The Ag NPs had a negative charge at $\mathrm{pH} \approx 6.8$ with a zeta potential of $-30.6 \pm 1.6 \mathrm{mV}$ in water (Figure S1d). The charges of Ag NPs further stabilized the nanoparticle suspension. Because all $\mathrm{Ag}$ NPs release $\mathrm{Ag}^{+}$ ions in solution, we then tested the PVP-coated Ag NPs (30 $\mathrm{nm}$ ) for $\mathrm{Ag}^{+}$release at a concentration of $30 \mathrm{mg} / \mathrm{mL}$ in DI water ( $\mathrm{pH}$ 6.8) and in simulated gastric juice ( $\mathrm{pH} \mathrm{1.2).} \mathrm{The} \mathrm{Ag}^{+}$ release from $\mathrm{Ag}$ NPs was approximately $0.1 \%$ and $0.5 \%$ in $24 \mathrm{~h}$ at $\mathrm{pH} 6.8$ and $\mathrm{pH}$ 1.2, respectively (Figure S1e, f). Ag NPs dispersed in acidic solutions may have a higher $\mathrm{Ag}^{+}$release. ${ }^{42,43}$ However, $\mathrm{Cl}^{-}$ions in simulated gastric juice might react with
$\mathrm{Ag}^{+}$to form insoluble $\mathrm{AgCl}$, resulting in a lower $\mathrm{Ag}^{+}$detected in simulated gastric juice with $\mathrm{pH}$ values as low as 1.2.

To select a proper dose of Ag NPs, we orally administered aqueous solution of Ag NPs at a daily dose of 100 or $300 \mathrm{mg} /$ $\mathrm{kg}$ to normal or overweight mice for 14 days (Figure 1a) and evaluated the Ag NP-induced general toxicity by monitoring the serum levels of alanine aminotransferase (ALT, Figure 1b), aspartate aminotransferase (AST, Figure 1c), alkaline phosphatase (ALP, Figure 1d), and creatinine (CREA, Figure 1e). Ag NPs increased the serum levels of ALT (Figure 1b) and AST (Figure 1c) in overweight mice at the dose of $300 \mathrm{mg} / \mathrm{kg}$, indicating potential toxic effects of $\mathrm{Ag} \mathrm{NPs}$ on the liver in overweight animals. Considering a potential future increase in environmental Ag NP levels and situations of longer exposure periods than that used here, and $300 \mathrm{mg} / \mathrm{kg}$ was used as the experimental dose of Ag NPs for daily exposure.

The amount of $\mathrm{Ag}^{+}$ions released from $\mathrm{Ag}$ NPs varies with the Ag NP coating. ${ }^{42,44,45}$ Under our experimental conditions, we detected only a $0.5 \% \mathrm{Ag}^{+}$release from PVP-coated Ag NPs (used in this study) at the dose applied. To reflect the highest dissolution amount reported in the literature, ${ }^{44}$ we used an $\mathrm{Ag}^{+}$ control with a presumed $6 \%$ dissolution $(18 \mathrm{mg} / \mathrm{kg})$. Therefore, HFD- and ND-fed mice were all exposed to Ag NPs at a daily dose of $300 \mathrm{mg} / \mathrm{kg}$ or an $\mathrm{AgNO}_{3}$ solution at an $\mathrm{Ag}^{+}$dose of $18 \mathrm{mg} / \mathrm{kg}$ for 2 weeks through oral gavage. 


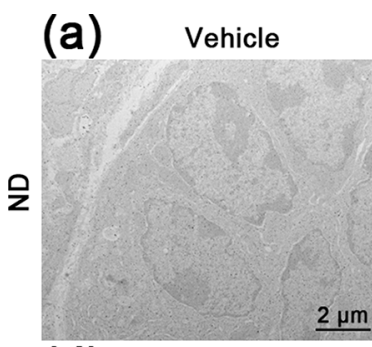

(d)

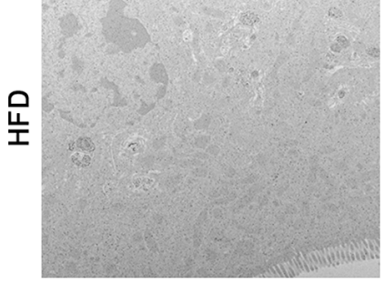

(b) Ag NPs

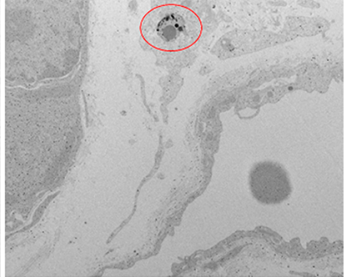

(e) (c) $\quad \mathrm{AgNO}_{3}$

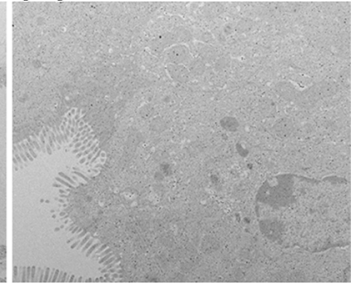

(f)

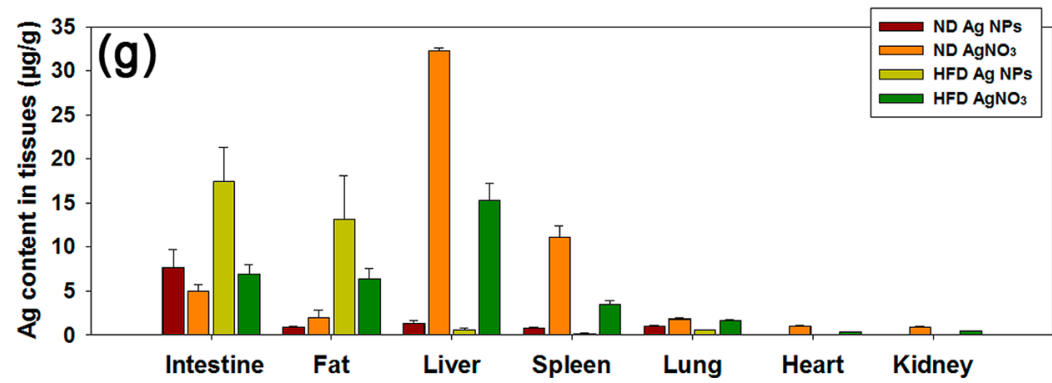

Figure 2. Intestinal absorption and distribution of $\mathrm{Ag} \mathrm{NPs} \mathrm{or} \mathrm{Ag}^{+}$in normal and overweight mice after oral administration of $300 \mathrm{mg} / \mathrm{kg} \mathrm{Ag} \mathrm{NPs} \mathrm{or}$ $18 \mathrm{mg} / \mathrm{kg} \mathrm{Ag}^{+}$solution. $(\mathrm{a}-\mathrm{f})$ Observation of Ag NPs in the small intestine of mice. Ag NPs were observed in the basement membrane of the small intestine after oral administration of Ag NPs in both the ND and the HFD groups, as shown in the red circles. (g) Ag content in various tissues. In $(\mathrm{g})$, data are shown as the means \pm s.d. ( $n=7$ per group).
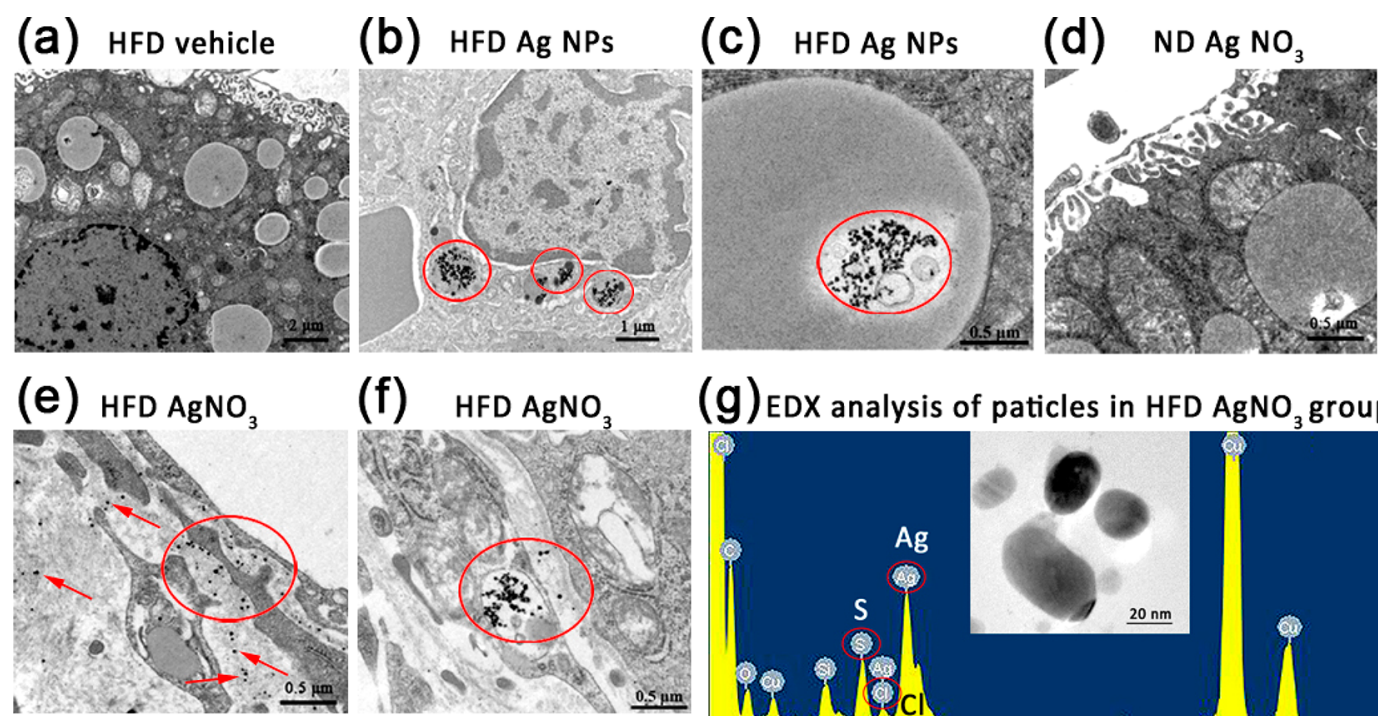

(g) EDX analysis of paticles in $\mathrm{HFD} \mathrm{AgNO}_{3}$ group
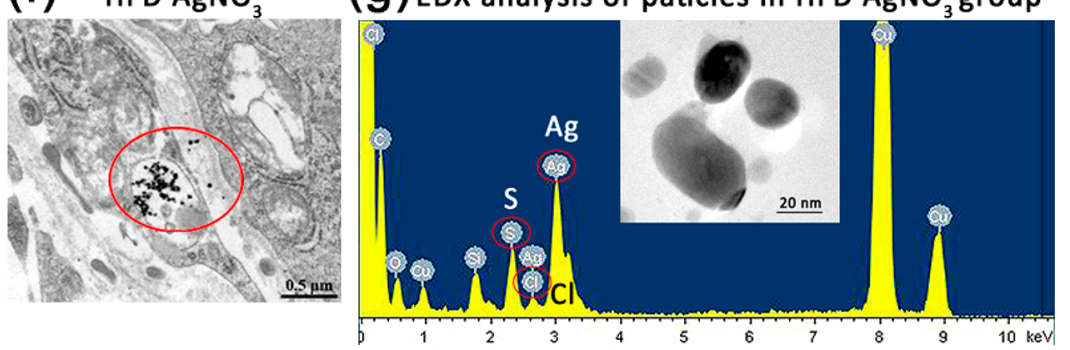

Figure 3. The subcellular localization of Ag NPs and in situ Ag NP formation in the livers of HFD mice. (a-f), TEM images of the liver slices of HFD-fed mice administered vehicle (a), Ag NPs (b, c), or $\mathrm{AgNO}_{3}(\mathrm{e}, \mathrm{f})$ and ND-fed mice administered $\mathrm{AgNO}_{3}$ (d). In the livers of HFD-fed mice, $\mathrm{Ag}$ NPs were observed in both Kupffer cells (b) and adiposomes of hepatocytes (c). After $\mathrm{AgNO}_{3}$ administration, $\mathrm{Ag}^{+}$cations were reduced to $\mathrm{Ag}$ NPs in the space of Disse (e) and the fibroblasts (f) of the livers of HFD mice but not ND mice (d). The location of nanoparticles is marked with red circles or arrows. EDX analysis of the observed nanoparticles in the livers of HFD mice treated with $\mathrm{AgNO}_{3}$ is shown in $(\mathrm{g})$.

Accumulation of Ag NPs in Major Organs. After oral administration of Ag NPs and $\mathrm{Ag}^{+}$to both ND and HFD mice for 2 weeks, mice were sacrificed, and the major organs were analyzed for the amount of Ag. It was found that a portion of
$\mathrm{Ag} \mathrm{NP}$ and most $\mathrm{Ag}^{+}$were absorbed (Figure 2a-f) and redistributed in all major organs, such as the liver, the spleen, the lung, the heart, and the kidney (Figure $2 \mathrm{~g}$ ), suggesting that both Ag NPs and $\mathrm{Ag}^{+}$ions were absorbed. However, the levels 

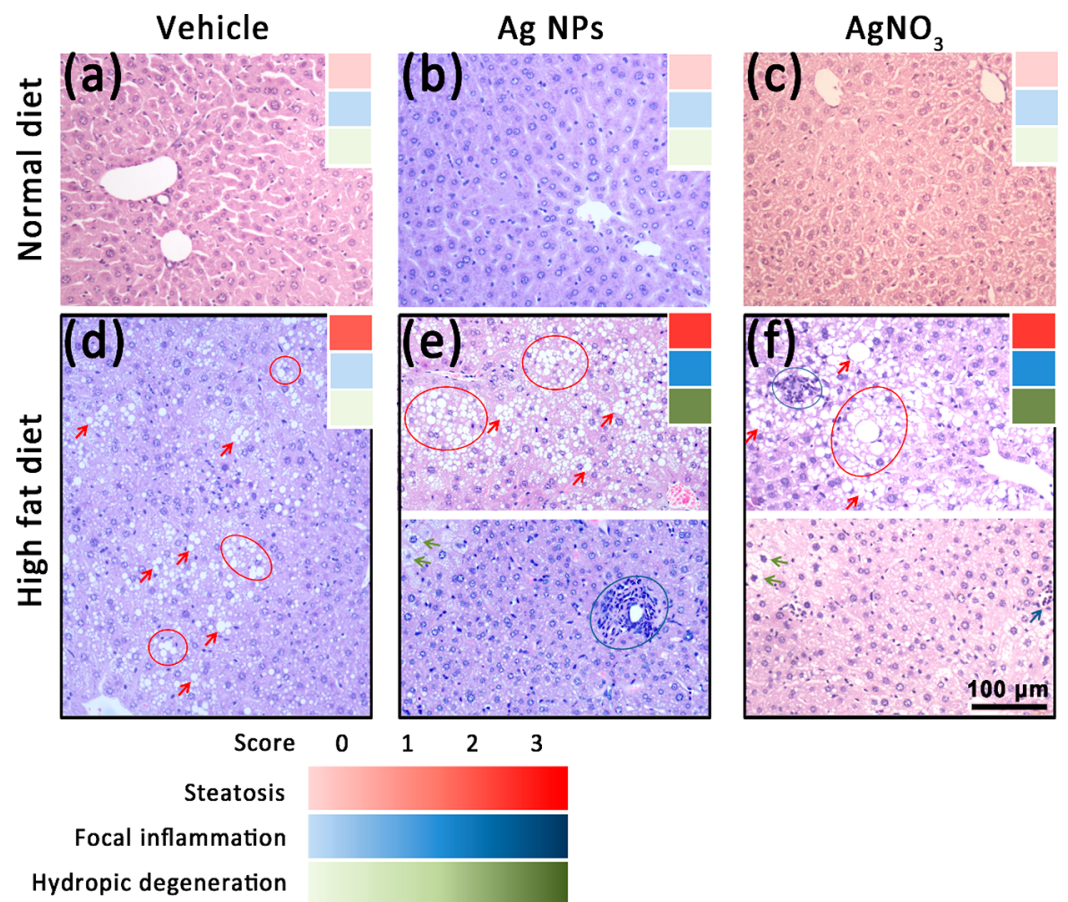

Figure 4. Ag NP-induced steatohepatitis based on pathological observations. Cross sections of the livers of ND mice stained with hematoxylin-eosin (H\&E) after administration of vehicle (a), Ag NPs (b), or $\mathrm{AgNO}_{3}$ (c). No significant steatosis, focal inflammation, or hydropic degeneration was observed when screening 70 images of liver samples from 7 mice. The cross sections of livers from HFD mice stained with $\mathrm{H} \& \mathrm{E}$ (d-f) after various treatments showed accelerated fatty liver disease in HFD mice caused by $\mathrm{Ag} \mathrm{NP}$ (e) and $\mathrm{AgNO}_{3}$ (f) exposure but not in the vehicle groups (d, g). Steatosis, focal inflammation, and hydropic degeneration are marked with red, blue, and dark green, respectively. The scores for steatosis, focal inflammation, and hydropic degeneration based on the images in pathological analyses of liver samples stained with H\&E are shown in the upper right corner of each panel.

of their absorption were different. Quantitative analyses of $\mathrm{Ag}$ revealed that the deposition of $\mathrm{Ag}^{+}$in the liver was 23.5- and 25.7-fold higher than that of Ag NPs for both ND and HFD mice. This trend was observed in all organs, indicating a much higher general absorption efficiency for $\mathrm{Ag}^{+}$compared to $\mathrm{Ag}$ NPs. Consistent with these results, more Ag NPs were found in the small intestine and the fat surrounding the small intestine (Figure 2g) in HFD mice. Therefore, a reduced amount of $\mathrm{Ag}$ NP crossing the small intestine and the trapping of Ag NPs in the surrounding fats were likely responsible for the reduced deposition of Ag NPs in various organs in both mice models, particularly for HFD mice.

Reduction of $\mathrm{Ag}^{+}$lons to $\mathrm{Ag}$ NPs in the liver of HFD mice. To identify the physical locations of Ag NPs in the liver, we examined slices of liver tissues with TEM (Figure $3 a-f$ ). Nanoparticles (diameter $\approx 30 \mathrm{~nm}$ ) were observed in both Kupffer cells (Figure 3b) and the adiposomes of hepatocytes (Figure 3c) in the livers of HFD mice after Ag NP treatment. To our surprise, after oral administration of an $\mathrm{AgNO}_{3}$ solution, nanoparticles with similar sizes were also observed in the space of Disse (Figure 3e) and fibrocytes (Figure 3f) in the livers of HFD mice, which were confirmed to be Ag NPs based on energy-dispersive X-ray emission spectra (EDX) analysis (Figure 3g). In addition to silver, significant sulfur signals but not chlorine were detected. In contrast, no nanoparticles were observed in the livers of ND mice after $\mathrm{AgNO}_{3}$ treatment, as determined by TEM examination of 120 liver images from three different ND mice (Figure 3d).

The observation by TEM of sulfur containing Ag NPs has also been reported in tissues such as the intestinal system ${ }^{46}$ and the kidney ${ }^{47}$ of rats exposed to ionic silver. In the liver, silver has been located using autometallographic straining. ${ }^{46,48}$ In the present study, no Ag NPs could be detected by TEM in livers of ND mice. This was in agreement with previous studies and could be related to either a very small size or a low number of the Ag NPs in the tissue. ${ }^{46}$ However, Ag NPs were detected in the space of Disse and the fibroblasts in livers of HFD mice. This suggested that not only formation of silver-sulfur nanoparticles but also reduction of $\mathrm{Ag}^{+}$to $\mathrm{Ag} \mathrm{NPs}$ might occur in the liver of HFD mice.

The mouse liver has a strong antioxidant capability. To explore the different reduction capabilities in the liver of ND and HFD mice, we first determined that the GSH concentrations in the livers of ND and HFD mice were 0.30 and $0.45 \mu \mathrm{mol} / \mathrm{mL}$, respectively, showing a $50 \%$ increase in HFD mice (Figure S3a). Using the concentrations of $\mathrm{Ag}^{+}$and GSH determined in the livers of HFD or ND mice, we then carried out the $\mathrm{Ag}^{+}$reduction experiments in vitro. Using a cloud point extraction method, ${ }^{49}$ we quantitatively determined that approximately $5 \%$ of the total $\mathrm{Ag}^{+}$ions deposited in the liver were reduced to $\mathrm{Ag} \mathrm{NPs}$, with a GSH concentration similar to that in the liver of HFD mice, while no Ag NPs were formed under the conditions mimicking ND mice (Figure $\mathrm{S} 3 \mathrm{~b}-\mathrm{d})$.

Ag NPs Caused a Progression from Steatosis to Steatohepatitis in HFD Mice. Oral administration of Ag NPs $([\mathrm{Ag}]=300 \mathrm{mg} / \mathrm{kg})$ or $\mathrm{AgNO}_{3}([\mathrm{Ag}]=18 \mathrm{mg} / \mathrm{kg})$ for 2 weeks did not change the body weight or organ coefficient in both ND and HFD mice (Figure S4). No behavioral abnormality was observed throughout the exposure period. On the basis of the observation that the highest Ag deposition was found in the liver after administration of either $\mathrm{Ag}$ NPs or $\mathrm{Ag}^{+}$(Figure 2g), 

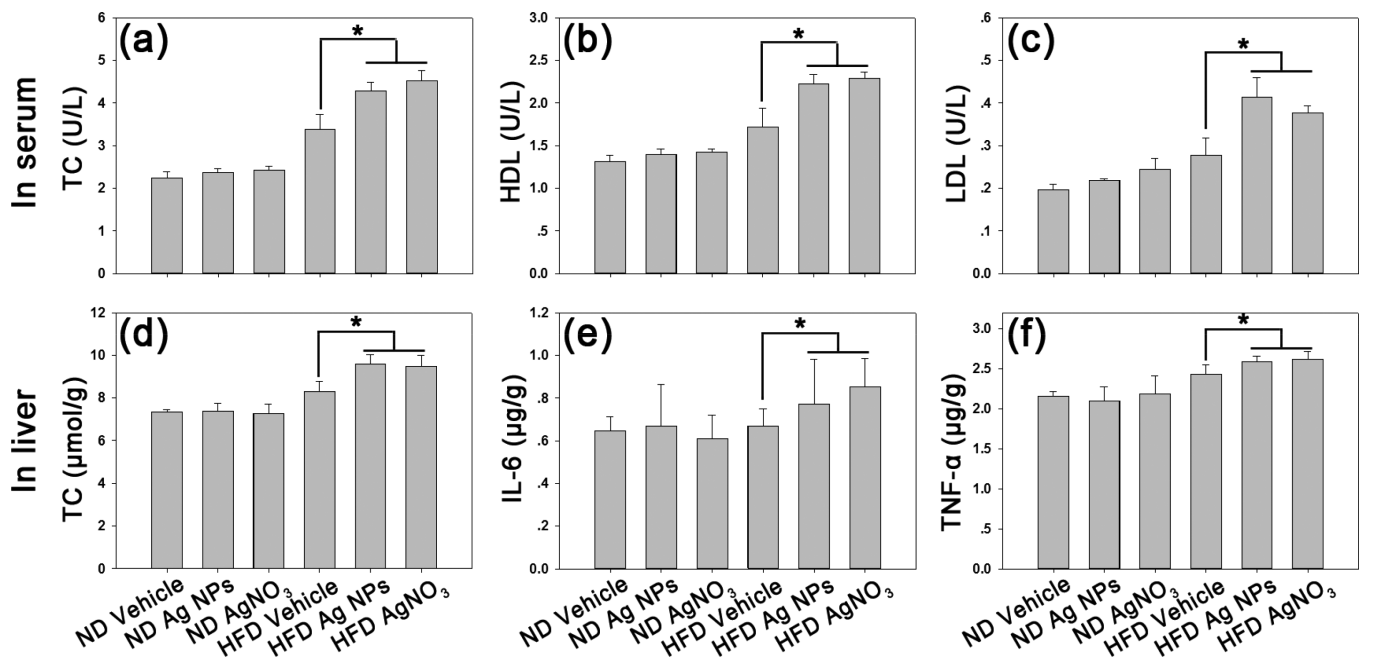

Figure 5. Ag NPs caused increased lipid accumulation and hepatic inflammation in HFD mice. (a-c) Serum TC (a), HDL (b) and LDL (c) levels after various treatments. (d) TC content in the liver. (e, f) Levels of the pro-inflammatory cytokines IL-6 (e) and TNF- $\alpha$ (f) in the liver. Data are shown as the means \pm s.d. $(n=7$ per group).
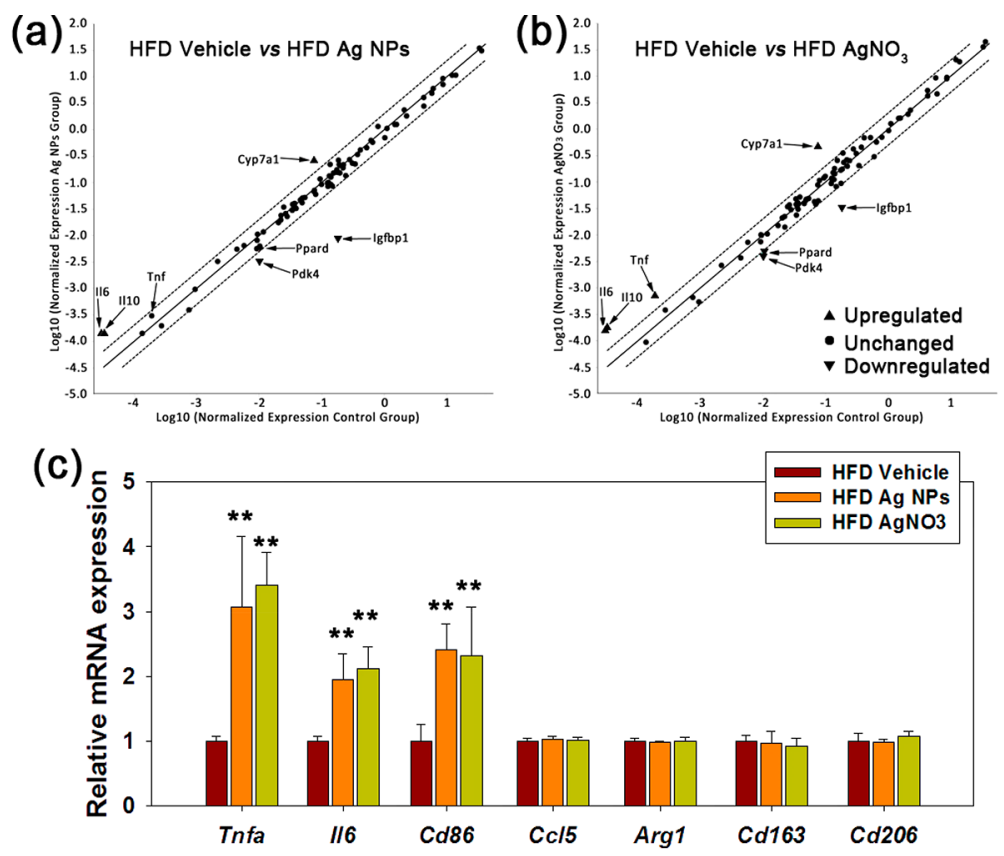

(d)
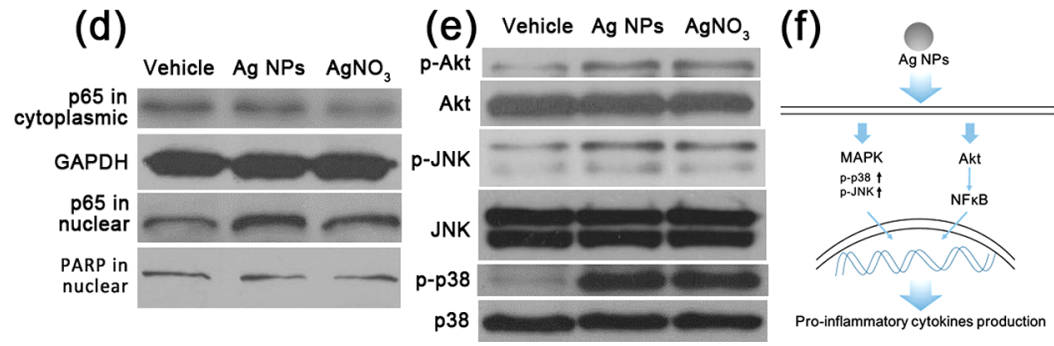

Figure 6. Ag NPs enhanced hepatic inflammation in HFD mice. (a, b) PCR array analysis of the expression of fatty liver-related genes in the livers of overweight mice after Ag NP or $\mathrm{Ag}^{+}$treatment. Genes involved in inflammation (Il6, Il10 and Tnfa) were upregulated, and genes related to fatty acid oxidation (Ppard and Pdk4) were downregulated. (c) Reverse transcription polymerase chain reaction (RT-PCR) analysis of genes related to the activation of Kupffer cells. Data are shown as the means \pm s.d. ( $n=7$ per group). (d, e) NF $\kappa$ B, Akt, JNK, and p38 MAPK activity in the livers of HFD mice analyzed by Western blotting. (f) A schematic showing the Ag NPs-induced production of pro-inflammatory cytokines.

we further analyzed the liver injury in ND and HFD mice. No evident pathological changes were observed after Ag NP or $\mathrm{AgNO}_{3}$ treatment for 2 weeks (Figure $4 \mathrm{a}-\mathrm{c}$ ) in the livers of
ND mice. In contrast, HFD feeding alone induced hepatic steatosis in HFD mice (Figures $4 \mathrm{~d}$ and S5a). To explore the detailed liver injuries, we examined the steatosis, focal 

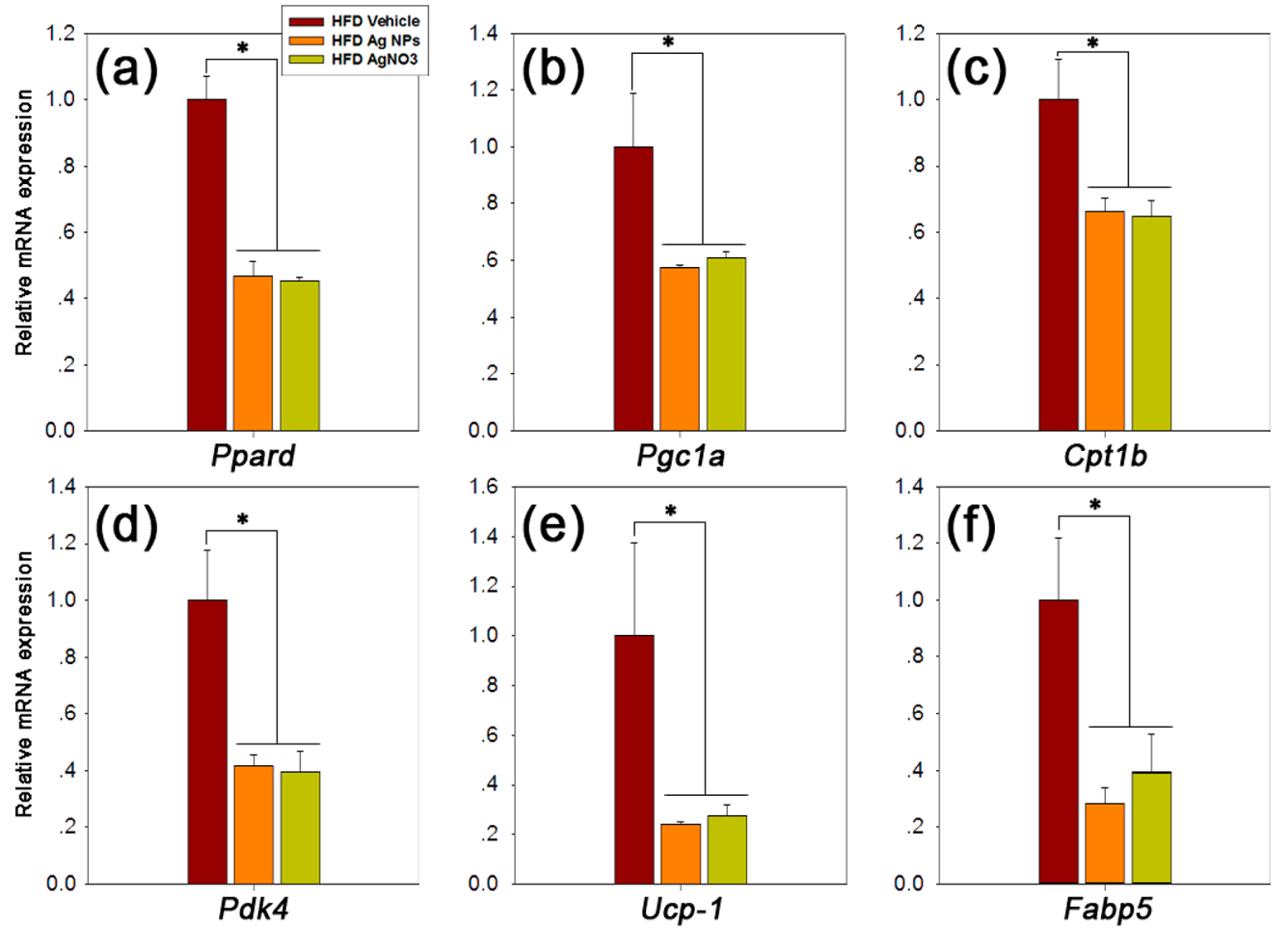

Figure 7. Reduced expression of Ppard and its target genes. Ag NPs exposure caused reduced expression of Ppard (a), its coactivator Pgc1a (b), and its target genes, including Cpt1b (c), $P d k 4$ (d), $U c p-1$ (e), and Fabp5 (f), in the liver. The reductions were all related to the inhibition of the fatty acid oxidation process. Data are shown as the means \pm s.d. $(n=7$ per group).

inflammation, and hydropic degeneration semiquantitatively by examination of 70 images from five liver slices for seven mice in each group. By counting the number of abnormal cells in each category, as represented by scores (Figure $4 a-f$ ), it was evident that both $\mathrm{Ag} \mathrm{NP}$ and $\mathrm{AgNO}_{3}$ administration in overweight mice led to a progression from hepatic steatosis to steatohepatitis, featuring inflammation and hydropic degeneration.

To further confirm the $\mathrm{Ag} \mathrm{NP}$ - or $\mathrm{AgNO}_{3}$-accelerated fatty liver disease in overweight mice at the molecular level, we examined the lipid levels in the blood and livers of mice and the pro-inflammatory cytokine production in the livers of both ND and HFD mice. Increased serum levels of total cholesterol (TC, $26 \%$ and $34 \%$ higher respectively, Figure 5a), high-density lipoprotein (HDL, 29\% and 33\% higher, respectively, Figure $5 \mathrm{~b}$ ) and low-density lipoprotein (LDL, 49\% and 35\% higher, respectively, Figure 5c) were observed in HFD mice treated with $\mathrm{Ag} \mathrm{NPs}$ or $\mathrm{AgNO}_{3}$. Quantitative analysis of liver samples showed an increase in hepatic TC levels (15\% and 14\% higher, respectively) in $\mathrm{HFD}$ mice after $\mathrm{Ag} \mathrm{NP}$ or $\mathrm{AgNO}_{3}$ treatment (Figure 5d). Ag NP or $\mathrm{AgNO}_{3}$ administration also increased the production of hepatic interleukin-6 (IL-6, Figure 5e) and tumor necrosis factor- $\alpha$ (TNF- $\alpha$, Figure 5f) in the livers of HFD mice, suggesting a higher level of hepatic inflammation in these mice. These results strongly corroborated the histopathological results and confirmed that $\mathrm{Ag} \mathrm{NPs}$ or $\mathrm{AgNO}_{3}$ accelerated the progression from hepatic steatosis to steatohepatitis.

Because of the $\mathrm{Ag}^{+}$-releasing property of $\mathrm{Ag} \mathrm{NPs}{ }^{50}$ we carefully compared effects from $\mathrm{Ag}$ NPs and $\mathrm{Ag}^{+}$treatments. We found that HFD mice were more sensitive than ND mice to Ag NP or $\mathrm{AgNO}_{3}$ exposures. More focal inflammation and hydropic degeneration of liver cells were found in livers of HFD mice after both exposures, indicating a disease progression from steatosis to steatohepatitis. The extent of toxicity based on either molecular assays or histopathological examinations was quite similar in both $\mathrm{Ag} \mathrm{NP}$ and $\mathrm{AgNO}_{3}$ groups, indicating that the liver doses of the causing agent were comparable in mice from these two groups. Comparing liver doses of $\mathrm{Ag}^{+}$and $\mathrm{Ag}$ $\mathrm{NP}$ in HFD mice treated by $\mathrm{AgNO}_{3}$ or $\mathrm{Ag} \mathrm{NPs}$, we found that the amount of $\mathrm{Ag}^{+}$in $\mathrm{AgNO}_{3}$ group was 400- to 4800-fold that in the $\mathrm{Ag} \mathrm{NP}$ group. This was because $\mathrm{Ag}^{+}$ions were efficiently absorbed, while Ag NPs were poorly absorbed. Alternatively, the amounts of Ag NPs in two groups were comparable $(0.60$ $\mu \mathrm{g} / \mathrm{g}$ vs $0.74 \mu \mathrm{g} / \mathrm{g}$ ) because only $5 \%$ of $\mathrm{Ag}^{+}$ions were reduced to $\mathrm{Ag} \mathrm{NPs}$ in fatty livers (Figure S3). These liver dose comparisons strongly indicate that it is Ag NPs deposited or formed in situ in the liver of HFD mice, not $\mathrm{Ag}^{+}$ions, that caused the disease progression.

Ag NPs Enhanced Hepatic Inflammation and Suppressed Fatty Acid Oxidation in HFD Mice. Nanoparticles perturb physiological functions by interfering with biomolecules and cellular signaling pathways. ${ }^{28,51-54}$ To explore the molecular mechanisms underlying the acceleration of fatty liver disease in overweight mice, we first analyzed the Ag NP- or $\mathrm{AgNO}_{3}$-induced expressions of 84 genes related to fatty liver disease in liver tissues of overweight mice using a fatty liverspecific $\mathrm{RT}^{2}$ Profiler PCR Array. The results showed that the PPAR- $\delta$ gene (Ppard) was downregulated, and several inflammation-related genes (such as Il10, Tnf, and Il6) were upregulated in the livers of overweight mice after treatment with $\mathrm{Ag} \mathrm{NPs}$ or $\mathrm{AgNO}_{3}$ (Figure 6a, b).

To further explore the possible inflammatory responses in the livers of HFD mice treated with Ag NPs, we examined the expression of genes reflecting the various activation states of Kupffer cells. It was found that Ag NP administration caused an increased expression of $\mathrm{Cd} 86$ and pro-inflammatory cytokines 
(Tnfa and Il6) in the livers of overweight mice, while no changes in the expression of M2 activation-related genes (Arg1, $C d 163$, and $C d 206$ ) were detected (Figure $6 \mathrm{c}$ ). These findings were also associated with the translocation of the $\mathrm{p} 65$ proteins into the nucleus (Figure 6d) and the increased phosphorylation of Akt, JNK, and p38 MAPK (Figure 6e). The schematic of Ag NP-induced production of pro-inflammatory cytokines was demonstrated in Figure 6f. These results indicated that Ag NP administration induced pro-inflammatory activation of the Kupffer cells, leading to an enhanced hepatic inflammation.

Nanoparticles are cleared from the systemic circulation by the mononuclear phagocyte systems involving monocytes and macrophages. ${ }^{55,56}$ Kupffer cells are specialized macrophages located in the liver. They are also major immune effector cells in the pathogenesis of nonalcoholic steatohepatitis. ${ }^{57}$ Kupffer cells trigger nonalcoholic steatohepatitis progression through TNF- $\alpha$ production. ${ }^{58}$ In this study, Ag NPs deposited or formed in situ in the liver of HFD mice induced the activation of Kupffer cells (Figure 6c), increased the production of proinflammatory cytokines including TNF- $\alpha$ (Figure 5e, f), and activated NF- $\kappa \mathrm{B}$ and MAPK signaling pathways (Figure $6 \mathrm{~d}, \mathrm{e}$ ), resulting in an enhanced hepatic inflammation.

In addition to inflammation, $\mathrm{Ag} \mathrm{NP}$ administration also induced suppression of Ppard expression, as shown in Figure $6 a, b$. Therefore, we further tested the expression of Ppard and its target genes to identify the effects of $\mathrm{Ag} \mathrm{NP}$ exposure on fatty acid metabolism. Our experimental results showed that the expression of Ppard (Figure 7a), its coactivator Pgcla (Figure $7 \mathrm{~b}$ ), and its target genes, including Cpt1b, Pdk4, Ucp-1, and Fabp5 (Figure $7 \mathrm{c}-\mathrm{f}$ ), were all downregulated by $\mathrm{Ag} \mathrm{NP}$ treatment.

PPAR- $\delta$ is a ubiquitous receptor that functions as a regulator of fatty acid oxidation in various tissues, including the liver. Activation of PPAR- $\delta$ attenuates hepatic lipid accumulation by inducing fatty acid oxidation in both animal models ${ }^{59,60}$ and human models. ${ }^{61}$ However, an increased level of TNF- $\alpha$ inhibits PPAR- $\delta$ activity, resulting in a downregulation of its target genes, including $P d k 4$ and $C p t 1 b .{ }^{62,63}$ The downregulation of PPAR- $\delta$ discovered in this work might cause a suppression of fatty acid $\beta$-oxidation and enhance the symptoms of hepatic steatosis. Therefore, the observed disease transition to steatohepatitis was caused by joint effects of inflammation and suppression of fatty acid oxidation.

Although potential toxicity from nanoparticles and their potential threats to human health have been frequently suggested, this pilot study emphasizes that such threats are increased for the susceptible overweight population. Although one needs to be cautious about translating mouse studies to human, the compelling findings from this study should raise concerns for the applications of or accidental exposures to $\mathrm{Ag}$ NPs in the overweight population.

\section{ASSOCIATED CONTENT}

\section{S Supporting Information}

The Supporting Information is available free of charge on the ACS Publications website at DOI: 10.1021/acs.est.7b02752.

Additional materials and methods and data on nanoparticle characterization, overweight mouse model establishment, systemic toxicity, $\mathrm{Ag}^{+}$ions reduction in fat mice liver, and AgNP-induced fatty liver disease progression (PDF)

\section{AUTHOR INFORMATION}

\section{Corresponding Author}

*Tel.: +8613969072308; e-mail: drbingyan@yahoo.com (B.Y.). ORCID $\odot$

Sijin Liu: 0000-0002-5643-0734

Bing Yan: 0000-0002-7970-6764

Notes

The authors declare no competing financial interest.

\section{ACKNOWLEDGMENTS}

We thank Chengke Zhang, Wenwei Wang, and Yilin Wang for their technical assistance. This work was supported by the National Key R\&D Program of China (2016YFA0203103), the National Natural Science Foundation of China (91543204 and 91643204), the Strategic Priority Research Program of the Chinese Academy of Sciences (XDB14030401), and the Natural Science Foundation of Shandong Province (ZR2014BM026).

\section{REFERENCES}

(1) Potera, C. NANOMATERIALS: Transformation of Silver Nanoparticles in Sewage Sludge. Environ. Health Perspect. 2010, 118 (12), A526-A527.

(2) Consumer Products Inventory. http://www.nanotechproject. org/cpi/products/ (May 26, 2017).

(3) Donovan, A. R.; Adams, C. D.; Ma, Y.; Stephan, C.; Eichholz, T.; Shi, H. Single particle ICP-MS characterization of titanium dioxide, silver, and gold nanoparticles during drinking water treatment. Chemosphere 2016, 144, 148-153.

(4) Mitrano, D. M.; Rimmele, E.; Wichser, A.; Erni, R.; Height, M.; Nowack, B. Presence of Nanoparticles in Wash Water from Conventional Silver and Nano-silver Textiles. ACS Nano 2014, 8 (7), 7208-7219.

(5) The Silver Institute, BACKGROUNDER Silver in medicinepast, present and future. https://www.silverinstitute.org/site/wpcontent/uploads/2017/01/SilverInMedicine.pdf.

(6) U.S. Public Health Service. Toxicological profile for silver. Agency for Toxic Substances and Disease Registry TP-90-24I 1990.

(7) Seiler, H. G.; Sigel, H.; Sigel, A. Handbook on Toxicity of Inorganic Compounds; Marcel Dekker: New York, 1988.

(8) Purcell, T. W.; Peters, J. J. Sources of silver in the environment. Environ. Toxicol. Chem. 1998, 17 (4), 539-546.

(9) Howe, P. D.; Dobson, S. Silver and silver compounds: environmental aspects. Concise International Chemical Assessment Document, 2002.

(10) Adegboyega, N. F.; Sharma, V. K.; Siskova, K.; Zbořil, R.; Sohn, M.; Schultz, B. J.; Banerjee, S. Interactions of aqueous $\mathrm{Ag}^{+}$with fulvic acids: mechanisms of silver nanoparticle formation and investigation of stability. Environ. Sci. Technol. 2013, 47 (2), 757-764.

(11) Hou, W.-C.; Stuart, B.; Howes, R.; Zepp, R. G. Sunlight-driven reduction of silver ions by natural organic matter: formation and transformation of silver nanoparticles. Environ. Sci. Technol. 2013, 47 (14), 7713-7721.

(12) Yin, Y.; Liu, J.; Jiang, G. Sunlight-induced reduction of ionic Ag and $\mathrm{Au}$ to metallic nanoparticles by dissolved organic matter. ACS Nano 2012, 6 (9), 7910-7919.

(13) Sharma, V. K.; Filip, J.; Zboril, R.; Varma, R. S. Natural inorganic nanoparticles-formation, fate, and toxicity in the environment. Chem. Soc. Rev. 2015, 44 (23), 8410-8423.

(14) Marchiol, L.; Mattiello, A.; Pošćić, F.; Giordano, C.; Musetti, R. In vivo synthesis of nanomaterials in plants: location of silver nanoparticles and plant metabolism. Nanoscale Res. Lett. 2014, 9 (1), 101.

(15) El-Said, W. A.; Cho, H. Y.; Yea, C. H.; Choi, J. W. Synthesis of metal nanoparticles inside living human cells based on the intracellular formation process. Adv. Mater. 2014, 26 (6), 910-918. 
(16) Pratsinis, A.; Hervella, P.; Leroux, J. C.; Pratsinis, S. E.; Sotiriou, G. A. Toxicity of silver nanoparticles in macrophages. Small 2013, 9 (15), 2576-2584.

(17) Ahamed, M.; AlSalhi, M. S.; Siddiqui, M. K. J. Silver nanoparticle applications and human health. Clin. Chim. Acta 2010, 411 (23-24), 1841-1848.

(18) Ogden, C. L.; Carroll, M. D.; Curtin, L. R.; McDowell, M. A.; Tabak, C. J.; Flegal, K. M. Prevalence of overweight and obesity in the United States, 1999-2004. JAMA 2006, 295 (13), 1549-1555.

(19) Collaboration, N. C. D. R. F. Trends in adult body-mass index in 200 countries from 1975 to 2014: a pooled analysis of 1698 population-based measurement studies with $19 \cdot 2$ million participants. Lancet 2016, 387 (10026), 1377-1396.

(20) Pienaar, A. E. Prevalence of overweight and obesity among primary school children in a developing country: NW-CHILD longitudinal data of 6-9-yr-old children in South Africa. BMC Obesity 2015, 2 (1), 1-10.

(21) World Health Organization, Obesity and overweight. (Fact sheet N 311). http://www.who.int/mediacentre/factsheets/fs311/en/

(22) Huxley, R. Metabolic mediators of the effects of body-mass index, overweight, and obesity on coronary heart disease and stroke: a pooled analysis of 97 prospective cohorts with 1. 8 million participants. Lancet 2014, 383 (9921), 970-983.

(23) Lazar, M. A. How obesity causes diabetes: not a tall tale. Science 2005, 307 (5708), 373-375.

(24) Taubes, G. Unraveling the obesity-cancer connection. Science 2012, 335 (6064), 28-32.

(25) Fabbrini, E.; Sullivan, S.; Klein, S. Obesity and nonalcoholic fatty liver disease: Biochemical, metabolic, and clinical implications. Hepatology 2010, 51 (2), 679-689.

(26) Morgan, B. Fatty liver disease: The liver labyrinth. Nature 2014, 516 (7529), S8-S9.

(27) Bai, Y.; Zhang, Y.; Zhang, J.; Mu, Q.; Zhang, W.; Butch, E. R.; Snyder, S. E.; Yan, B. Repeated administrations of carbon nanotubes in male mice cause reversible testis damage without affecting fertility. Nat. Nanotechnol. 2010, 5 (9), 683-689.

(28) Gao, N.; Zhang, Q.; Mu, Q.; Bai, Y.; Li, L.; Zhou, H.; Butch, E. R.; Powell, T. B.; Snyder, S. E.; Jiang, G.; Yan, B. Steering Carbon Nanotubes to Scavenger Receptor Recognition by Nanotube Surface Chemistry Modification Partially Alleviates NF $\kappa \mathrm{B}$ Activation and Reduces Its Immunotoxicity. ACS Nano 2011, 5 (6), 4581-4591.

(29) Kim, Y. S.; Kim, J. S.; Cho, H. S.; Rha, D. S.; Kim, J. M.; Park, J. D.; Choi, B. S.; Lim, R.; Chang, H. K.; Chung, Y. H.; Kwon, I. H.; Jeong, J.; Han, B. S.; Yu, I. J. Twenty-Eight-Day Oral Toxicity, Genotoxicity, and Gender-Related Tissue Distribution of Silver Nanoparticles in Sprague-Dawley Rats. Inhalation Toxicol. 2008, 20 (6), 575-583.

(30) van der Zande, M.; Vandebriel, R. J.; Van Doren, E.; Kramer, E.; Herrera Rivera, Z.; Serrano-Rojero, C. S.; Gremmer, E. R.; Mast, J.; Peters, R. J. B.; Hollman, P. C. H.; Hendriksen, P. J. M.; Marvin, H. J. P.; Peijnenburg, A. A. C. M.; Bouwmeester, H. Distribution, Elimination, and Toxicity of Silver Nanoparticles and Silver Ions in Rats after 28-Day Oral Exposure. ACS Nano 2012, 6 (8), 7427-7442.

(31) Zhang, Y.; Bai, Y.; Jia, J.; Gao, N.; Li, Y.; Zhang, R.; Jiang, G.; Yan, B. Perturbation of physiological systems by nanoparticles. Chem. Soc. Rev. 2014, 43 (10), 3762-3809.

(32) Cha, K.; Hong, H.-W.; Choi, Y.-G.; Lee, M.; Park, J.; Chae, H.K.; Ryu, G.; Myung, H. Comparison of acute responses of mice livers to short-term exposure to nano-sized or micro-sized silver particles. Biotechnol. Lett. 2008, 30 (11), 1893-1899.

(33) Cohen, J. C.; Horton, J. D.; Hobbs, H. H. Human Fatty Liver Disease: Old Questions and New Insights. Science 2011, 332 (6037), $1519-1523$.

(34) Imajo, K.; Fujita, K.; Yoneda, M.; Nozaki, Y.; Ogawa, Y.; Shinohara, Y.; Kato, S.; Mawatari, H.; Shibata, W.; Kitani, H.; Ikejima, K.; Kirikoshi, H.; Nakajima, N.; Saito, S.; Maeyama, S.; Watanabe, S.; Wada, K.; Nakajima, A. Hyperresponsivity to Low-Dose Endotoxin during Progression to Nonalcoholic Steatohepatitis Is Regulated by Leptin-Mediated Signaling. Cell Metab. 2012, 16 (1), 44-54.

(35) Wigg, A.; Roberts-Thomson, I.; Dymock, R.; McCarthy, P.; Grose, R.; Cummins, A. The role of small intestinal bacterial overgrowth, intestinal permeability, endotoxaemia, and tumour necrosis factor $\alpha$ in the pathogenesis of non-alcoholic steatohepatitis. Gut 2001, 48 (2), 206-211.

(36) Brunt, E. M.; Janney, C. G.; Bisceglie, A. M.; NeuschwanderTetri, B. A.; Bacon, B. R. Nonalcoholic steatohepatitis: a proposal for grading and staging the histological lesions. Am. J. Gastroenterol. 1999, 94 (9), 2467-2474.

(37) Kleiner, D. E.; Brunt, E. M.; Van Natta, M.; Behling, C.; Contos, M. J.; Cummings, O. W.; Ferrell, L. D.; Liu, Y.-C.; Torbenson, M. S.; Unalp-Arida, A.; Yeh, M.; McCullough, A. J.; Sanyal, A. J. Design and validation of a histological scoring system for nonalcoholic fatty liver disease. Hepatology 2005, 41 (6), 1313-1321.

(38) Zhang, H.; Shi, Z.; Liu, Y.; Wei, Y.; Dai, J. Lipid homeostasis and oxidative stress in the liver of male rats exposed to perfluorododecanoic acid. Toxicol. Appl. Pharmacol. 2008, 227 (1), 16-25.

(39) Barnett, A.; Eff, C.; Leslie, R. D.; Pyke, D. Diabetes in identical twins. Diabetologia 1981, 20 (2), 87-93.

(40) Karam, J. H.; Grodsky, G. M.; Forsham, P. H.; McWilliams, N. B. Excessive insulin response to glucose in obese subjects as measured by immunochemical assay. Diabetes 1963, 12 (3), 197-204.

(41) Long, R.; Zeng, W.; Chen, L.; Guo, J.; Lin, Y.; Huang, Q.; Luo, $\mathrm{S}$. Bifidobacterium as an oral delivery carrier of oxyntomodulin for obesity therapy: inhibitory effects on food intake and body weight in overweight mice. Int. J. Obes. 2010, 34 (4), 712-719.

(42) Elzey, S.; Grassian, V. Agglomeration, isolation and dissolution of commercially manufactured silver nanoparticles in aqueous environments. J. Nanopart. Res. 2010, 12 (5), 1945-1958.

(43) Peretyazhko, T. S.; Zhang, Q.; Colvin, V. L. Size-Controlled Dissolution of Silver Nanoparticles at Neutral and Acidic pH Conditions: Kinetics and Size Changes. Environ. Sci. Technol. 2014, 48 (20), 11954-11961.

(44) Ma, R.; Levard, C.; Marinakos, S. M.; Cheng, Y.; Liu, J.; Michel, F. M.; Brown, G. E.; Lowry, G. V. Size-Controlled Dissolution of Organic-Coated Silver Nanoparticles. Environ. Sci. Technol. 2012, 46 (2), 752-759.

(45) Tejamaya, M.; Römer, I.; Merrifield, R. C.; Lead, J. R. Stability of Citrate, PVP, and PEG Coated Silver Nanoparticles in Ecotoxicology Media. Environ. Sci. Technol. 2012, 46 (13), 7011-7017.

(46) Loeschner, K.; Hadrup, N.; Qvortrup, K.; Larsen, A.; Gao, X.; Vogel, U.; Mortensen, A.; Lam, H. R.; Larsen, E. H. Distribution of silver in rats following 28 days of repeated oral exposure to silver nanoparticles or silver acetate. Part. Fibre Toxicol. 2011, 8, 18-18.

(47) Creasey, M.; Moffat, D. The deposition of ingested silver in the rat kidney at different ages. Experientia 1973, 29 (3), 326-327.

(48) Danscher, G.; Locht, L. J. In vivo liberation of silver ions from metallic silver surfaces. Histochem. Cell Biol. 2010, 133 (3), 359-366.

(49) Yu, S.-j.; Chao, J.-b.; Sun, J.; Yin, Y.-g.; Liu, J.-f.; Jiang, G.-b. Quantification of the uptake of silver nanoparticles and ions to HepG2 cells. Environ. Sci. Technol. 2013, 47 (7), 3268-3274.

(50) Lubick, N. Nanosilver toxicity: ions, nanoparticles-or both? Environ. Sci. Technol. 2008, 42 (23), 8617-8617.

(51) Mu, Q.; Du, G.; Chen, T.; Zhang, B.; Yan, B. Suppression of human bone morphogenetic protein signaling by carboxylated singlewalled carbon nanotubes. ACS Nano 2009, 3 (5), 1139-1144.

(52) Zhang, Y.; Mu, Q.; Zhou, H.; Vrijens, K.; Roussel, M. F.; Jiang, G.; Yan, B. Binding of carbon nanotube to BMP receptor 2 enhances cell differentiation and inhibits apoptosis via regulating bHLH transcription factors. Cell Death Dis. 2012, 3, e308.

(53) Mu, Q.; Jiang, G.; Chen, L.; Zhou, H.; Fourches, D.; Tropsha, A.; Yan, B. Chemical Basis of Interactions Between Engineered Nanoparticles and Biological Systems. Chem. Rev. 2014, 114 (15), $7740-7781$.

(54) Wu, L.; Zhang, Y.; Zhang, C.; Cui, X.; Zhai, S.; Liu, Y.; Li, C.; Zhu, H.; Qu, G.; Jiang, G. Tuning cell autophagy by diversifying 
carbon nanotube surface chemistry. ACS Nano 2014, 8 (3), 20872099.

(55) Saba, T. M. Physiology and physiopathology of the reticuloendothelial system. Arch. Intern. Med. 1970, 126 (6), 10311052.

(56) Bertrand, N.; Leroux, J.-C. The journey of a drug-carrier in the body: An anatomo-physiological perspective. J. Controlled Release 2012, 161 (2), 152-163.

(57) Lefkowitch, J. H.; Haythe, J. H.; Regent, N. Kupffer cell aggregation and perivenular distribution in steatohepatitis. Mod. Pathol. 2002, 15 (7), 699-704.

(58) Tosello-Trampont, A.-C.; Landes, S. G.; Nguyen, V.; Novobrantseva, T. I.; Hahn, Y. S. Kuppfer cells trigger nonalcoholic steatohepatitis development in diet-induced mouse model through tumor necrosis factor- $\alpha$ production. J. Biol. Chem. 2012, 287 (48), 40161-40172.

(59) Bojic, L. A.; Telford, D. E.; Fullerton, M. D.; Ford, R. J.; Sutherland, B. G.; Edwards, J. Y.; Sawyez, C. G.; Gros, R.; Kemp, B. E.; Steinberg, G. R.; Huff, M. W. PPAR $\delta$ activation attenuates hepatic steatosis in $\mathrm{Ldlr}^{-/-}$mice by enhanced fat oxidation, reduced lipogenesis, and improved insulin sensitivity. J. Lipid Res. 2014, 55 (7), 1254-1266.

(60) Tanaka, T.; Yamamoto, J.; Iwasaki, S.; Asaba, H.; Hamura, H.; Ikeda, Y.; Watanabe, M.; Magoori, K.; Ioka, R. X.; Tachibana, K.; Watanabe, Y.; Uchiyama, Y.; Sumi, K.; Iguchi, H.; Ito, S.; Doi, T.; Hamakubo, T.; Naito, M.; Auwerx, J.; Yanagisawa, M.; Kodama, T.; Sakai, J. Activation of peroxisome proliferator-activated receptor $\delta$ induces fatty acid $\beta$-oxidation in skeletal muscle and attenuates metabolic syndrome. Proc. Natl. Acad. Sci. U. S. A. 2003, 100 (26), 15924-15929.

(61) Risérus, U.; Sprecher, D.; Johnson, T.; Olson, E.; Hirschberg, S.; Liu, A.; Fang, Z.; Hegde, P.; Richards, D.; Sarov-Blat, L.; Strum, J. C.; Basu, S.; Cheeseman, J.; Fielding, B. A.; Humphreys, S. M.; Danoff, T.; Moore, N. R.; Murgatroyd, P.; O’Rahilly, S.; Sutton, P.; Willson, T.; Hassall, D.; Frayn, K. N.; Karpe, F. Activation of Peroxisome Proliferator-Activated Receptor (PPAR) $\delta$ Promotes Reversal of Multiple Metabolic Abnormalities, Reduces Oxidative Stress, and Increases Fatty Acid Oxidation in Moderately Obese Men. Diabetes 2008, 57 (2), 332-339.

(62) Cimini, A.; Bernardo, A.; Cifone, G.; Di Muzio, L.; Di Loreto, S. TNF $\alpha$ downregulates PPAR $\delta$ expression in oligodendrocyte progenitor cells: Implications for demyelinating diseases. Glia 2003, 41 (1), $3-14$.

(63) Serrano-Marco, L.; Chacón, M. R.; Maymó-Masip, E.; Barroso, E.; Salvadó, L.; Wabitsch, M.; Garrido-Sánchez, L.; Tinahones, F. J.; Palomer, X.; Vendrell, J.; Vázquez-Carrera, M. TNF- $\alpha$ inhibits $\operatorname{PPAR} \beta / \delta$ activity and SIRT 1 expression through NF- $\kappa$ B in human adipocytes. Biochim. Biophys. Acta, Mol. Cell Biol. Lipids 2012, 1821 (9), 1177-1185. 